\title{
Local Government Strategy in Fostering Traditional Market Competitiveness through Revitalization (A Study at Pemalang Traditional Market)
}

\author{
$1^{\text {st }}$ I Gede Eko Putra Sri Sentanu ${ }^{1}, 2^{\text {nd }}$ Akbar Noor Muhammad Wijayanto ${ }^{2},{ }^{3 \text { rd }}$ Fahmi \\ Firmansyah $^{3},{ }^{4 \text { th }}$ Mahadiansar $^{4},{ }^{5 \text { th }}$ Fannidya Hamdani Zeho ${ }^{5}$ \\ \{ sentanu@ub.ac.id', akbarnoormw@gmail.com², dhenfahmi99@gmail.com ${ }^{3}$, \\ mahadiansar@student.ub.ac.id ${ }^{4}$, fanni.zeho@yahoo.com $\left.{ }^{5}\right\}$
}

Universitas Brawijaya, Jalan MT. Haryono No. 163 Kota Malang Jawa Timur, Indonesia ${ }^{1}$ Universitas Brawijaya, Jalan MT. Haryono No. 163 Kota Malang Jawa Timur, Indonesia ${ }^{2}$ Universitas Pancasakti Tegal, Jalan Halmahera Mintaragen Kota Tegal Jawa Tengah ${ }^{3}$ Universitas Brawijaya, Jalan MT. Haryono No. 163 Kota Malang Jawa Timur, Indonesia ${ }^{4}$ Universitas Brawijaya, Jalan MT. Haryono No. 163 Kota Malang Jawa Timur, Indonesia ${ }^{5}$

\begin{abstract}
Revitalization of traditional markets is an effort conducted by the government in fostering economic development, local government revenue (PAD), and fair competitiveness in global competition. Besides, the implementation of traditional market revitalization faces various problems. One of them is a relocation of traders while the market is being revitalized, budget management for traditional market revitalization, and competent human resources in traditional market revitalization programs. Therefore, the appropriate strategy in facing those problems is needed. The appropriate strategy must cover the achieving process, the goal, and the result of traditional market revitalization programs. Furthermore, a descriptive method along with a qualitative approach is employed in this study. Moreover, the focus of this study is the strategy of local government in traditional market revitalization programs covering: organization strategy, program, the sources, and institution. This study involves three leading sectors, as cooperative service and industry and trade of UMKM (big and small business agency), Pemalang trade, Paduraksa market, section chief of Diskoperindag (cooperative industry and trade agency), and grocery market. The data of this study were then analyzed by employing the Miles and Huberman analysis model with the NVivo application. The results of this study indicate that three important things should be taken into consideration: 1) adjusting the budget to the revitalized target market based on the needs and conditions of the traditional market. 2) Providing socialization to the market traders related to the purpose and the goal of revitalization. 3) Providing the strategy in adjusting human resources involved in traditional market revitalization programs. The involvement of human resources in this program reflects the solid cooperation in developing and fostering the economy of Pemalang.
\end{abstract}

Keywords: Strategy, revitalization, traditional market, competitiveness, NVivo. 


\section{Introduction}

Traditional market revitalization is an effort to improve the quality of public space conducted by the local government together with the citizens and the private sector. The aim of traditional market revitalization covers not only the improvement in the physical infrastructure of traditional markets but also the market management. It includes the arrangement of the shops, market retribution, parking area of the market, market cleanliness management, the founding of the traders, the involvement of the traders in market management, empowerment of the commodities so they can be well-managed that they can attract the interest of the consumers, and the improvement on traditional market security.

The good management of traditional markets along with the active contribution from the local government and citizens can bring a positive impact to the economic continuity of traditional markets and enable them to compete against modern markets. Traditional market revitalization is also a solution in creating public space concerning more comfort. However, implementing traditional market revitalization without careful planning can also bring bad impact.

Furthermore, it is important to foster acquisitiveness and concern on the traditional market revitalization as the traditional market itself represents the democracy of the economy itself. It provides affordable prices and direct bargaining that cannot be found in the modern market. However, the problem existing in the traditional market before it has not been revitalized is there is no standardized regulation in traditional markets as in modern markets such as mini market, hypermarket, and supermarket. They have far better facilities and management than traditional markets. Due to this, citizens, especially the youngsters, prefer the modern market to the traditional market. The current paradigm of traditional markets existing in the society is that traditional markets lack cleanliness and facilities. They assume that cleanliness and facilities in traditional markets do not meet the good market standard. In addition to this, traditional market traders are generally bad-behaved in terms of their services. It causes the consumers to feel uncomfortable during the trading process. It also leads them to grow doubtfulness and insecurity. For example, there are some unfair traders. They are being unfair in calculating the goods they sell. They increase the price carelessly and ignore the market management by ignoring the settled range price given by the modern market. Therefore, fostering the traditional market revitalization including not only physical infrastructure but also integrated market regulation systems that do not ignore the uniqueness of traditional markets is important to be conducted.

Nowadays, the traditional market is becoming more and more important to be concerned about. It is due to the citizens and society from various ranges can easily access it. Unfortunately, traditional market revitalization in Indonesia has not been fully implemented. Thus, traditional markets cannot contribute more to foster the economy of a medium and lower society. Revitalization is aimed at enhancing the development of the traditional market's role and its function to enable the traditional market to compete against the modern market. Hence, the comfortable trading of the citizen and society in traditional markets can run smoothly. Besides, traditional market revitalization can also improve the welfare of the traders in terms of obtaining the big turnovers; improve the logistic distribution both in export and import leading to the market strengthening in the country.

Traditional market revitalization brings an advantage not only to the traditional market traders and the society but also to the government and private sector in several regions. These advantages are: 
1. The increasing income of the traditional market traders in general [1], as traditional market revitalization provides well-systemized financial management. It is systematized by employing technology settled in its management,

2. The consumers can do trading comfortably as it has good cleanliness, good services, and good facilities [1]. Thus, the consumer will trust the services in the traditional market as it provides the systemized bills for each transaction which have already adjusted to the common market price.

3. The comfortable, clean, well serviced, and good facilities have resulted in traditional market revitalization. It can satisfy the consumer in doing comfortable trading. It also gets the consumer to trust the services in traditional the market as it provides systemized bills for each transaction based on the common adjusted market price,

4. The well-developed public space management and the local government revenue can be obtained successfully by the government [2]. The strategic revitalized location will be equipped with good facilities that caused the traditional market is always visited by the citizen,

5. The investment from the private sector into the traditional market to enhance the purchasing power of the traditional market can be improved by revitalization [3]. Although investment is characterized as something modern, traditional markets have big potential to obtain investment from those who are concerned about following the culture of the traditional market.

Moreover, several traditional markets, such as Denpasar, successfully conduct the revitalization by managing the traditional market, involving the government's role in integrating traditional market from the cultural aspect, tourism aspect in the city; and educating the traders who do not have appropriate knowledge and understanding in traditional market management [4]. Today, the central government is focusing on obtaining the target of traditional market revitalization by decreasing the market classification based on various types. It is conducted to achieve the event market revitalization in each regency. The classification of traditional markets is conducted by considering the conditions of the market that will be revitalized including its size, numbers of shops, width, and the numbers of traders in that market. All of them will be studied by both local and central governments [5].

Table 1.

Budget Allocation of the Targeted Revitalized Traditional Markets based on their classification types in 2019 [Ministry of Trade, 2019]

\begin{tabular}{lll}
\hline No. & Market Types & Budget \\
\hline 1 & A Type & Rp. 11,5 Billion \\
2 & B Type & Rp. 7,7 Billion \\
3 & C Type & Rp. 5,8 Billion \\
4 & D Type & Rp. 3,6 Billion \\
5 & E Type & Rp. 1,1 Trillion \\
\hline
\end{tabular}

Examples of successful traditional markets are Pasar Agung and Poh Gading market in Denpasar. It is due to the providence of good management training and direct guidance that both markets acquire a license or certificate of Indonesian National Standard (INS) from the Indonesian Ministry of Trade. The exact reason for this success is because the Denpasar government develops the market school to educate the market traders about public ethics so that they can create a friendly and trusted traditional market 
In 2020, the traditional market revitalization is focused by the central government, through the Ministry of Public Works and Public Housing of Republic Indonesia, on four traditional markets such as Pariaman market of Pariaman, West Sumatra; Kaliwungu market of Kendal, East Java; Klewer market of Central Java; and Sukati market of Bali. The revitalization concept implemented by the central government is adjusted to the local values in those regions which are based on a Democracy economy. Besides, this year, the Ministry of Trade through its policy revitalizes 1037 traditional markets in Indonesia as the previous traditional market revitalization's result indicates the increasing turnover of about 20\%. Meanwhile, the local policy through its role in each area will revitalize traditional markets based on the revitalization concept of the sustainable food sector by adding UMKM and improving it.

In contrast to this, the revitalization of the traditional market also has several obstacles such as the lack of good cooperation among the traders. It implies that the trust of traditional parties has not been considered seriously by the investors; the complicated regulations made by the government and private sector in participating in the implementation of traditional market revitalization which leads to the area dispute in traditional market are; the lack of political approach to the traditional market owner in the process of revitalizing traditional market; there is no even distribution in the abandoned areas which lead the traditional market trader to assume that revitalization is merely for political business. Despite these, traditional market revitalization also has supporting factors such as the empowerment of human resources through the traditional market founding. It affects the significant increasing income to the market traders after being implemented [6].

The revitalization of traditional markets is aimed at maintaining the old culture, the old tradition, and the culture of the traditional market as the icon of Indonesia which are reflected in societies' behaviors. It is hoped that it will be able to be the trademark of the Indonesian traditional market on an international level. The future of the traditional market can compete against the modern market as the need for global development from time to time without losing the essence of the traditional market itself. In addition to this, the future of revitalization depends on the government's concern on market revitalization itself, as the revitalization management has a great amount of budget without a supervisory agency to supervise the revitalization process. Therefore, this agency is needed to avoid the misuse of the revitalization budget. Moreover, traditional market revitalization in Indonesia has good prospects as it is in line with the needs of the society from time to time. However, it can also lead to failure if the needs of society are in abundance, which makes traditional market revitalization programs unable to fulfill the traditional market needs based on its standard if it is compared to other countries in Asia.

Therefore, what the local and central government need to do is to take a step of the strategy by involving the government and private sector in every aspect such as economic aspect, physical aspect, and social aspect. These three aspects are very important and play an important role as a win to win solution in developing traditional market revitalization strategy in Indonesia. It also enables the governments to avoid conflicts in society. Therefore, the government needs to form an educational program for the traditional market traders. It is due to the lack of understanding of traditional market traders about standardization and well-systematic management of traditional markets. This understanding is very crucial in fostering competitiveness in complying with the needs of qualified human resources. It refers to those traders who are capable of managing traditional markets well. 


\section{Methodology}

\subsection{Research Type}

This study provides two data including primary and secondary data. Primary data is obtained directly from the sources while secondary data is obtained from the previous data which are related to the investigated problem. It is also provided from the additional data source which supports the primary data [7: 132]. Furthermore, the primary data collected in this study are obtained by performing direct interviews. It is conducted to the chief of cooperative agency and industry and trade of UMKM; the chief of the Market agency in market facilitation division; the chief of Paduraksa market; the chief of grocery market; and the herbs traders and the greengrocers.

Besides, secondary data are obtained by collecting the documented and written data which are considered important to observe the investigated problem and the object of this study so that the researcher can obtain the complete and valid data [8: 158]. Government performance accountability report (LAKIP) of logistic directory and distribution of facility along with the final report analysis of the development of the traditional market is employed as the main research instruments in analyzing this study.

\subsection{Focus of the Study}

The focus of this study is decided by conducting the observation through direct interaction and communication of the evidence, occurrences, and the parties involving in three sectors as the leading sector, cooperative service, and industry and trade of UMKM of Pemalang, Paduraksa market, section chief of Diskoperindag, and groceries market.

The phenomenon in the focus of this study is very interesting and attractive to the researchers as it contains a deep meaning to be studied. It can also become a way to deeply understand the aspect of implementing good management of traditional markets and. Besides, it can also become an active role for the government and society as it brings positive impact to the economic continuity of society.

\subsection{Data Collection}

In a qualitative study, the data collection refers to an effort of limiting the study; collecting the information through observation, interview, documentary, visual materials; and designing the protocol in recording and documenting the information [9:189].

\section{In-depth Interview}

An in-depth interview refers to a data collection method that involves the interviewer and the interviewee to discuss the specific topic deeply. In this method, the interviewer and the interviewee are not only performing question and answer but also observing the reaction and body language of each other which represent their relation built during the interview [10: 109].

The in-depth interview model chosen employed in this study refers to the semi-structured interviews. At the beginning of the interview, the researcher performs open-ended questions. After that note is continued by a specific discussion based on the interviewee's answers. The interview guidelines containing the main points are still designed and occupied by the researcher. However, they are only used to smoothen the interview and smoothen data and information collection. These will be supported well by the researcher's improvisation in performing the interview related to the investigated topic. This model is chosen as an in-depth interview containing reserve problems about the interview time, how the order is, how the 
reformulated question is, and others that commonly appear spontaneously as the situation development of the interview itself [11: 68].

The main research instrument in this in-depth interview employs a voice recorder and the researcher field notes. The researcher employs two field notes covering descriptive notes and reflective note. The descriptive note covers the detailed information about location, situation, occur that noted other things observed by the researcher. They are documented and written the way they are. The researchers do not involve personal judgment and personal opinion in documenting descriptive notes. Moreover, a reflective note contains the researcher's responses about the result of the interview covering both logical and ethical responses upon what the researchers listen, look, and feel. Both of these notes are needed in supporting the researcher to analyze the interview transcript [12: 122-123].

\section{Document}

The document refers to a note including rules, literature, news, and operational report of the investigated object. Document plays a role as additional information in completing data source and guidance to keep the research steps on the right track. Document analysis or documentation study refers to a way to collect data that results in a written document which is important to investigate the problem related to the investigated objects. Thus, complete and valid data can be obtained [8].

\subsection{Data Analysis}

Data analysis refers to a systematic way of managing, integrating, testing, finding pattern and relation of the data in detailed way. In order to conduct data analysis, the data and evidence must be connected to the concept, advanced generalization, and identification results of the theme so that there will be a possibility to correct the understanding, to broaden the theory, and to improve the knowledge [13: 477]. The Miles and Huberman analysis model along with NVivo applications are employed in this study. NVivo in this study refers to the tool utilized to manage as it interwoven to Miles and Huberman analysis.

\section{Miles dan Huberman Analysis Model}

Miles and Huberman analysis refers to the technique of analyzing data continuously until the data fully obtained in specific time [14]. The model chosen is an interactive analysis model. The answers obtained in the interviews and observations are analyzed directly. If the results obtained have not met the standard, then the interview and observation will be re-conducted until the credible data are obtained. It also works the same in the documentation process. Once the data obtained, they are directly reduced and presented. Then, the permanent conclusion is drawn. Then, it is verified to the participant giving the document in the first step or to other participants. After that, the data collection is conducted once more. It is conducted interactively and continuously until the data are fully obtained. Specifically, the steps in analyzing data in this study consist of three steps. They are: data reduction; data presentation; and data verification along with drawing the conclusion.

In data reduction, the abundance, complex, and complicated data are formalized. Then, they are sorted based on the main concern. Then, they are specified to the same categories. After that, they are sorted and classified based on their patterns' similarities. The reduced data provide the clear representation and makes the following data collection become easier. It also makes the search of those data become easier when they are needed to identify, analyze, and present the pattern in the data. The reduction step is started by understanding the data, coding, theming, 
observing the theme, identifying and naming the theme, sorting the theme that contribute to the research [15: 15-23].

In data presentation, the reduced data is presented into descriptive narration in order to comprehend the understanding and to plan the research activity based on the previous understanding [13: 496]. In presenting the data, analysis through providing the explanation about the related case, answering the question, and matching the pattern by comparing the recent condition to the ideal condition [16: 106-111].

In data verification and conclusion drawing, the conclusion is drawn based on the proposed research question. Then, the conclusion is adjusted to fit the result of the explanation and the settled pattern that are matched before.

Generally, the process of Miles and Huberman 's data analysis explained previously can be specified by Putra (2011: 204) as follows.

1) All of the field notes are divided into paragraphs or sentences.

2) After that, they are coded based on their categories.

3) All of the categorized field notes that have been coded are entered to certain categories.

4) These categories are investigated related to their relations to obtain the holistic meanings.

5) Final conclusions are drawn.

\section{Data Management with NVivo 11 software}

NVivo is a computer program equipped to analyze qualitative data which enable a person to import and code the textual data; to edit the text, to take, observe, and decode the coded data; to find the combination of words in text or their patterns in coding; and to import and export the data from or to the other qualitative analysis software. The advantage of employing NVivo lays on its ability to form the way to read data (from static to dynamic) by creating the relation among categories which are more visible in text form and hyperlink the categories to other documents [17: 2].

NVivo developed by International QSR in 2006 to 2017 has the last and completed version released as NVivo 11 Plus for Windows. The newest version of this software has big advantage for the researcher in assisting the researcher to manage data such as entering and analyze the photos, pictures, and videos; analyzing the data source from email, news, or report in website; analyzing the information obtained from social media such as Facebook, Twitter, and LinkedIn; and inserting the online videos from YouTube [18: 2].

\section{Finding and Discussion}

\subsection{Traditional Market Competitiveness}

The concept of competitiveness is generally related to the concept of comparative advantage and competitive advantage. The factors of comparative advantage are slightly depending on the level of relative sources owned by certain companies which are also known as competitive advantage [19]. These two factors are the main factors that play a big role in fostering competitiveness. Furthermore, Porter (2008) explains about five forces strategies in Industrial competition. They are: (1) threat of substitute, (2) rivalry among existing competitors, (3) threat of new entrants, (4) bargaining power of suppliers, and (5) bargaining power of buyers.

\section{a. The Concept of Competitiveness of the Traditional Market - Traditional Market VS} Modern Market

Based on The Decree of President of Indonesia No. 112 in 2007 and the Regulations of Minister of Internal Affairs Number 70/M-DAG/PER/12/2013 about The Guidelines for 
Structuring and Guiding Traditional Markets, Shopping Centers, and Modern Stores, a traditional market is a market built and controlled by government, local government, private parties, State-Owned Enterprises, and Regional Owned Enterprises that cooperates with private enterprises such as shops, booths, and tend owned by small traders with small scale business, small modal, and by processing the buying and selling the goods at a bargain. On the other hand, a modern marker based on The Decree of President No. 112 in 2007 is a market or shop by using an independent service system that sells various kinds of goods in retail in the form of mini market, supermarket, department store, hypermarket or groceries. Sinaga (2006) in Perespersik (2006) added that a modern market is a market controlled by modern management that generally takes place in urban areas. Besides, the modern market provides goods and services with good quality and service for consumers.

The modern market, nowadays, grows fast, and in the middle of modernization currents, the traditional market is demanded to exist and develops to be able to compete with the modern market [24]. The competitiveness in economy and in micro level (company level) is defined as: (1) the company ability to dominate, to develop, and to maintain the market apposition; (2) the company ability to solve the market changes and competition in Indonesia and to enlarge and maintain the profitability, market share, and/or the business measurement in the scale of business; (3) the capacity of profitability to sell the product (Sinaga, 2013: 45 in Perespersik, 2006). Moreover, according to Porter (2008: 90) the competitiveness of business can be explained as the business ability of a company in the industry to face various environments.

The rapid development and the establishment of the modern market give the effect for the existence of the traditional market. The traditional and modern market compete in the same market that is retail $[25,26]$. In the context of the traditional market, the word "competitiveness" is the ability of the traditional market to maintain and increase its profitability of the market share continuously through utilizing its competitive advantage [27: 61]. On other words, the ability of the traditional market is maintaining its consumers to keep shopping.

Therefore, it cannot be denied that the traditional market has high roles for the economy. Because of that reason, the government must strive for the traditional marker to be an appropriate place that can make consumers interested [28]. The revitalization of the market is an effort to increase the competitiveness of the traditional market with the modern market. It does not only increase the economy but also put a halt to the emerging modern market. So, the existence of the traditional market must be rearranged and can be equal to the modern market. In line with the matter, based on the result of the research by Rosyidi et al. (2016) explained that the implementation of the revitalization of the traditional market in Ir. Soekarno market, Sukoharjo regency gets positive effect both in service and in adding security facilities, cleanliness, making the park area, an open area that can answer the needs of consumers to the traditional market. Mangeswuri \& Purwanto (2010) added that the revitalization of the markets in Indonesia can be done to increase and to empower the market as the appropriate place. Besides, the existence of the traditional market is not inferior to the modern market. The revitalization must be supported by the facilities of security, convenience, cleanliness and orderliness.

\section{b. Traditional Market in Disruptive Era}

The presence of the modern marker with modern management at first does not influence the traditional marker because it is expected that the presence of the modern market becomes the solution for the upper middle-class society. Nevertheless, along with the development of the knowledge, the technology, and the changes in lifestyle, the needs of the society also increase the complexity of the society's demand for shopping easily and efficiently. The presence of the 
modern markets actually gives the benefit for the consumer, but it becomes a threatening innovation for the presence of the traditional markets $[30,31]$. The threat by Christensen \& Bower (1995) is called disruptive innovation.

The disruption basically is an innovation that will change all of the old system or old people (incumbent) with the new ways or new people (start-up). The disruption has the potential to change the old players with the new ones. It can be seen as a positive thing because it is a dynamic, efficient, effective and modern innovation [33; 27]. Finally, the disruptive era creates a new market called a digital marketplace. The shopping activity can be done through cyberspace that is easy for people to make transactions [34].

Kasali (2017) explained that there are five important things in the disruption, as follows: first, disruption means cost saving through the easier business process. Second, the quality of the produced products/services become better. Third, disruption has the potential to create the new market and make the things which have been closed to be open. Fourth, the produced products/services are easily reached by the society because people only need Internet networks and gadgets, and lastly, the produced products/ services are smarter.

In the disruptive era, the market tries to create the new innovation of the market that can fulfil the needs of global society. The progress of knowledge and technology also gives a huge effect for the existence of the recent markets. The needs of the society are getting easier shopping and do not need to spend more time. In regard with these matters, the start-up innovates to create a new market that can fulfil the recent demand. In order to maintain the traditional market in this competition, the traditional market must be able to offset the demands by analyzing the factors influencing the competitiveness in the disruptive era.

Moreover, recent technology is the important thing that influences the era. It gives convenience and practicality to answer the demands of society nowadays. The progress of technology helps the efforts of the government to fix the management system of the traditional market to be able to maintain its existence and competitiveness. The government starts to make digitization of the traditional market. In the disruptive era, digitization of the traditional market is a breakthrough to fix the market system. The example of digitization toward the traditional market in Indonesia is Etanee Food Marketplace. It is a digital technology that can link the seller with the buyer (supply-demand) despite the distance. N.I Ariyani \& Nurcahyono (2018) stated about the implementation of digitization in the traditional market by using the billboard list of the food prices. It can protect the prices in avoiding the increasing prices or fraud done by the sellers in the market. Besides, it can be the competitiveness of the traditional market to be able to compete in the disruption era. The digitization concept of the traditional market is believed to keep the stability of supplies and prices in the market and to make society easy to do the activities and transactions safely and comfortably.

\section{c. The Revitalization of the Traditional Market the Revitalization of Market toward the Increase of Locally-Generated Revenue}

The revitalization of the traditional market is an effort to keep and to develop the traditional market with the law regulation and forms the program to control the traditional market. Based on Danisworo \& Martokusumo (2000) revitalization is an effort to rebuild or to revitalize a city that experiences slackness because of the current development. The revitalization of the traditional market is very beneficial to give the real effects for the income of the sellers and can increase the locally-generated revenue (PAD -Pendapatan Asli Daerah) by good management and bases on Standard Operating Procedures (SOP) [37-40]. Revitalization does not only rearrange the building but also gives the empowerment about good arrangements of goods and sales methods [41]. Regarding these matters, each region needs to make a regulation about the 
revitalization of the traditional market to give the real effect toward the sellers and the development of the economy through the traditional market sector.

Local revenue is manifestation of a regional development financing. One of the revenues comes from the traditional market. Defitri (2011) stated that local revenue through intensification of the sources, one of the sources, comes from the retribution of market service. The market has the important role and link to local revenue. It supports the regional economy. In this case, the existence of the traditional market must get more attention from the local government. In line with the current development, the traditional market will lose from the modern market. The effort to keep the existence of the traditional market is doing the revitalization of the market to increase the local revenue as well.

Moreover, revitalization is an effort to fix the physical conditions of a building and to fix the condition of the management of public organization or public area. In line with the traditional market, revitalization of the traditional marker can be used to support and to push the economic sector in the traditional market area. It needs good preparation in the beginning of the implementation of revitalization until the step of managing the traditional market. The failure of revitalization in the traditional market happens in the management sector because of some reasons. The retribution of the seller is not accurate, the management of the parking area is unclear, the management of the market trash is not good enough, and the market manager does not have a clear vision and mission.

The effect of the failure influences the local revenue. One of the purposes from revitalization of the traditional market is increasing the local revenue, but the thing happening reserves for the local government. It does not only deserve the local area but the sellers also deserve because of the unclear management revitalized. To solve the failure, it is needed to choose the competence and experience of human resources in the traditional market field. The first input must prepare and choose the strategies that will be used and done in the process of revitalizing the traditional market. The strategy of choosing the agency used as the leading sector must be paid attention so that authority overlaps do not occur. The next strategy is adjusting the budget of the local government with the revitalized market.

Other resources are the main factors in succession of revitalizing the traditional market. The market managers, sellers, and other agencies must cooperate with the leading sector. Besides, the private parties sometimes become the investor or the parties that control the implementation of revitalization. It also needs the socialization and coordination between the involved parties in order to avoid miss-communication in implementing the revitalization of the traditional market.

The output of revitalization can work well. The market management before, on-going, and after revitalization can work well as the purposes. The outcome also increases the local revenue. The traditional market takes place as one of the sources of local revenue. Based on the government regulation No. 66 in 2001 about the local retribution, the traditional market is an object of local retribution including in the group of general services, so it can be categorized as the source of local revenue.

The success of revitalizing the traditional market in increasing the local revenue is already done by Surakarta city. The success of policy evaluation toward the revitalization of the traditional market gives benefit both for the sellers and for the buyers. We can see how the market gives convenience and security from some aspects such as the condition of market building, market yard, market facilities, market circulation, and market surveillance. After revitalization, the condition of the market is better in lighting, cleanliness maintained, and neatly arranged yard. Besides, other improvements are the lighting that utilizes natural lighting, better security supervision, and things supporting the management of the market that become well 
maintained. In addition, the policy about the prohibition of buskers and beggars begins to be intensified. The good and structured management and the certain law for the seller are done to arrange the management of the traditional market. The purpose of revitalization is fulfilling and supporting the needs of the public such as convenience, cleanliness, security, and availability of infrastructure. Besides, it is expected that the revitalization of the traditional market can increase the income of the sellers and the local revenue.

\section{d. The Local Government Strategies in Encouraging the Competitiveness of the Traditional Market: the Research of Traditional Market in Pemalang}

There are 17 traditional markets in Pemalang regency. All of them are the legacy of new order, so the buildings are already old. To support the progress of the economic sector, these markets make the revitalization program. The program is based on the degree of President No. 112 in 2007 about Structuring and Guiding Traditional Markets, Shopping Centers, and Modern Stores.

Table 4.1 the Number of Traditional Market in Pemalang Regency [Diskoperindag, 2016-2021]

\begin{tabular}{llc}
\hline No. & \multicolumn{1}{c}{ Name of Traditional Market } & Market Type \\
\hline 1 & Pemalang City Market & Class I \\
2 & Petarukan Market & Class I \\
3 & Comal Market & Class I \\
4 & Ulujami Market & Class II \\
5 & Banjardawa Market & Class II \\
6 & Bantarbolang Market & Class II \\
7 & Randudongkal Market & Class I \\
8 & Paduraksa Market & Class II \\
9 & Pemalang Morning Market & Class I \\
10 & Warungpring Market & Class III \\
11 & Sruwet Market & Class II \\
12 & Petapean Market & Class II \\
13 & Pelutan Market & Class I \\
14 & Belik Market & Class II \\
15 & Moga Market & Class II \\
16 & Bojongbata Market & Class II \\
17 & Vegetables and Fruits Market & Class II \\
\hline
\end{tabular}

Table 4.2 the Revitalized Traditional Market [Diskoperindag, 2016-2021]

\begin{tabular}{lll}
\hline No. & Revitalized Market in 2016-2019 & Completion of Revitalization of the Traditional Market \\
\hline 1 & Ulujami Market & Finish \\
2 & Banjardawa Market & Finish \\
3 & Pelutan Market & Finish \\
4 & Bojongbata Market & Finish \\
5 & Belik Market & Finish \\
6 & Paduraksa Market & Finish \\
7 & Vegetables and fruits Markets & Process of moving to a new place \\
8 & Randudongkal Market & Process of building the market \\
& & \\
\hline
\end{tabular}


Each policy or program basically has a leading sector in implementing the policy and program. Leading sector has the strategy and controls it in order to increase the local revenue at Pemalang from the revitalization of the traditional market. Mr. Hepi Priyanto as the Head of Cooperative Service and UMKM of Industry and Commerce stated that;

"Revitalization program of the traditional market states un 27 priority programs in RPJMD 20162021. To support this program, we, Diskoperindag, based on job description as the leading sector legally do and implement the program. By revitalizing the traditional market through 27 program strategies in RPJMD, it is very helpful for us to work. It means that the availability of funds to revitalize the traditional market help us and other parties to work. Diskoperindag, managers of the traditional markets, and the seller are the organization that has the purpose to make the traditional market exist, to develop the activities in the traditional market, to give convenience for the customers, to manage the traditional market by involving the sellers, and to make the market not only as shopping center but also as a public area that is safe and comfortable. This process is still ongoing."

Until now, there are eight traditional markets that get the program of revitalizing, and one of them is still finishing before all sellers are moved to the new market. This program is very useful especially for the development of the economy of Pemalang. With regard to it, how is the strategy of revitalizing the traditional market implemented? Mr. Sakdudin as the Head of Market Sector comments about it that;

"Whatever the policy and the program revitalize the traditional market has the strategy to implement and succeed the program. The strategy in revitalizing the traditional market is increasing the infrastructures of the market that aren't appropriate yet as the healthy market. The characterizations of a healthy market are the maintained cleanliness of the market, the availability of garbage bins in every corner of the market, and the properly functioning drainage system. Besides, there is a loading and unloading separator of goods, there is the availability of adequate cleaning staff, and the market is protected from muddy and other dirty things. To solve these matters, we already prepare the supporting facilities for the market such as in Paduraksa Market that uses retribution systems by using electronic systems to avoid fraud. There is only one market that uses this electronic system, but gradually it will be implemented for other markets. This strategy is still ongoing although the program of revitalization is already done. It is caused by all facilities that need care and rejuvenation, so this program will continue for the convenience of the customers of the traditional market."

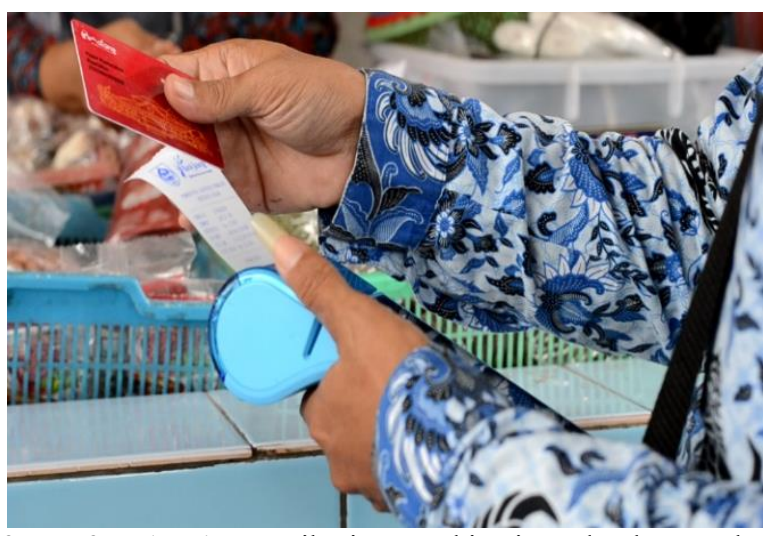

Figure 4.1 the form of card and E-Retribution Machine in Paduraksa Market (Researchers' documentation) 


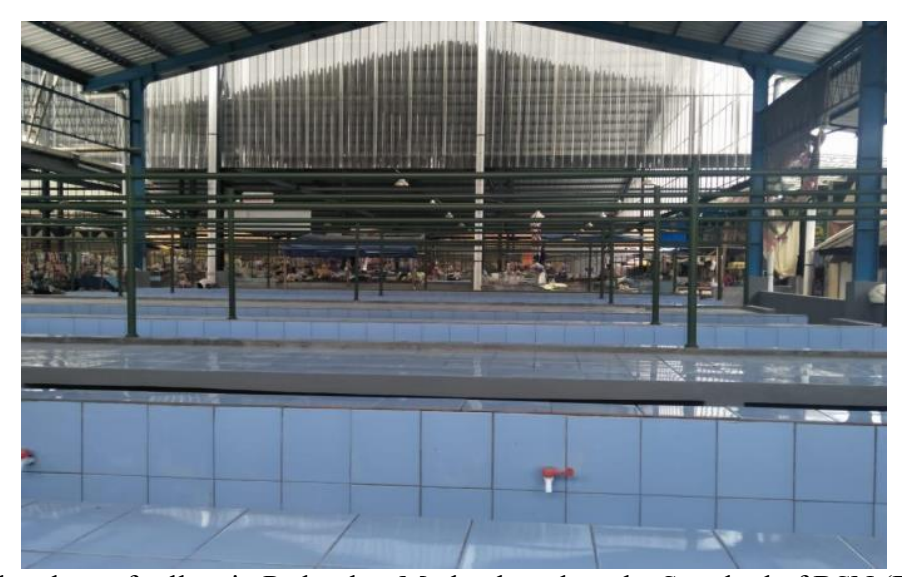

Figure 4.2 the place of sellers in Paduraksa Market based on the Standard of BSN (Researchers' documentation)

Other supporting resources in the program of revitalizing the traditional market are very needed to make the program successful. The utilization of supporting resources make the problems narrow in implementing the revitalization of the traditional market. So that, the strategy to utilize and support the supporting resources is needed to make a positive outcome. Dealing with it, the Head of Market Sector stated that;

"Regarding the strategy to maximize the supporting resources, we don't only need our resources, they can come from the utilization of technology to support the program of revitalization and the funds that we must have to finance the revitalization. Actually, humans, technology, and funds will work well if we can organize them well. First, from the human resource we cooperate with the managers of the markets, other agencies, sellers, and other private parties to succeed this program. These human resources can be beneficial for succeeding this program if we can control them well, and vice versa. So that, we need a commitment, socialization, and scheduled coordination to maximize the revitalization program. Second, the technology also helps us to communicate and to report the field condition. Besides, the fund is an important thing to fulfil all we need for succeeding the revitalization program. Without it, I am sure that this program will only be a written form without any realization. These three strategies will be done to support our supporting resources and to maximize this program."

Diskoperindag as the leading sector has a responsibility to do the revitalization of the traditional market. Regarding the strategies of this institution, they must be prepared and done for succeeding the program of revitalization. Dealing with it, Mr. Hepi Priyanto stated that:

"Talking about the strategies of the institution, Diskoperindag of Pemalang regency is an institution that has responsibility to revitalize the traditional market. The strategies are already stated in our vision and mission of Pemalang regency in 2016-2021. The Regional Head and the Deputy Regional Head include 27 priority programs of Pemalang regency. The program of revitalizing the traditional market is already reported once every three months in the meeting for all institutions. In this meeting, we explain our results throughout the program. The strategies of the institution are also discussed during the meeting to find out the next strategies that we can use to maximize the program. The regional head and deputy regional head give the instruction to do the program by cooperating between the institutions and other parties well and directed. Family approaches to succeed in the program are always done. The lack of funds and the transparency of the funds must 
be solved in order to maximize the program and make the society of Pemalang feel satisfied with our work. Besides, it also can increase the local revenue."

\section{Literature Maps}

Literature maps is a visual review from the researches and theories done by the experts presented in the form of pictures with various ways such as hierarchy, flowchart, or with pie chart [9: 36]. In software NVivo, one of the outputs from its project map is a literature map that visualizes the ideas and concepts in form of chart or graphics based on the theories reviewed by the experts. Literature map is very important in this study since it aims to explore main ideas from the research data. NVivo Literature map is a part of the project map. Project map is a map that aims to explore and to organize the data; to identify the pattern, theory, and the explanation that appears; to represent virtually the relationship among those projects; and to give the record in a project.

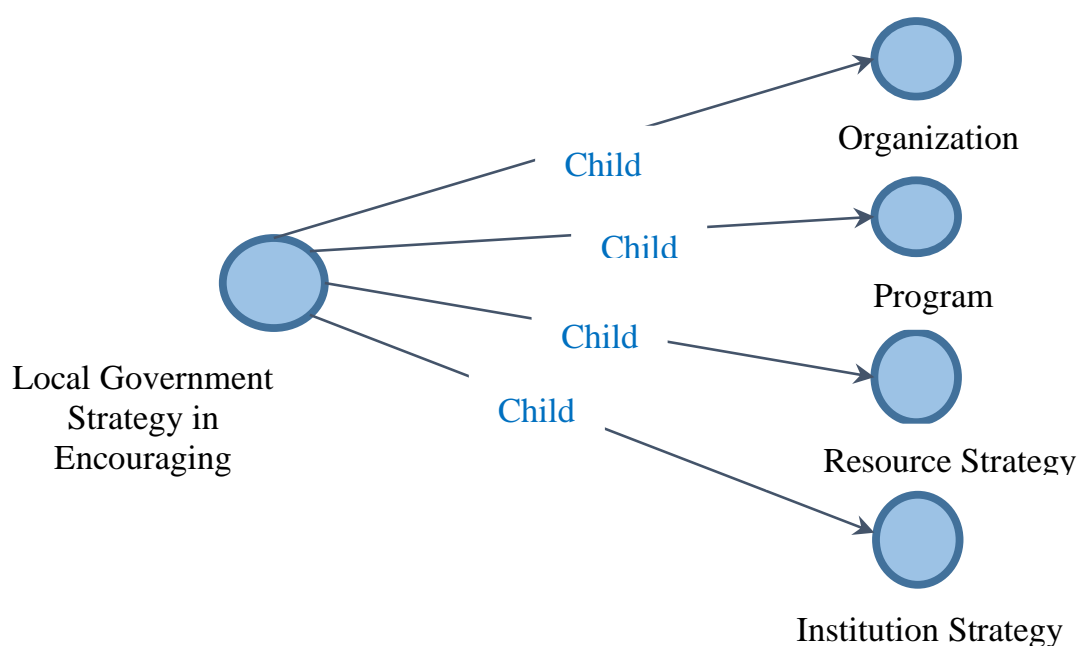

Figure 4.3 the Researcher Analysis by NVivo 11

In other words, every region has their strategies in conducting and making the regional priority program successful. Collaboration between local government agencies both vertical and horizontal needs to be strengthened. The existence of the program must be based on the welfare of the community and regional development. It aims to encourage the progress of an area in creating public services to the community.

This strategy has an objective to guide in implementing the traditional market revitalization program. Moreover, the researcher used strategy theory from J. Salusu (2015) in combining and comparing the study in the field. Here the further explanation:

\section{Cooperative Strategy}

This strategy connects with the formulation of new missions, goals, values, and the latest strategic initiatives. The restrictions are needed in order to inform what is done and for who is 
doing it. Mission, objectives, values, initiatives are very decisive as an organization in carrying out and implementing strategies.

Organization strategy refers to the agency as the leading sector in the traditional market revitalization strategies namely Department of Industry and Commerce of Pemalang Region. The latest organization strategy for budget planning that will later fund the traditional market revitalization process. The target around 2 years traditional market will be revitalized and it will be realized based on the Government Performance Accountability Report 2019-2020. Organization strategy in the Department of Industry and Commerce takes the advantages of the existing budget by revitalizing traditional markets. This budget should be enough with $100 \%$ absorption.

Supervision is a part of The Department of Industry and Commerce strategy both before revitalization, the revitalization, the revitalization process and after traditional market revitalization. The supervision is usually done in the field and it is about how far the market development project, the team readiness in the field are the officers in maintaining the security of market improvement and overseeing budget use. To maximize this revitalization program, supervision is carried out thoroughly by involving other institutions such as the Police and TNI. Then, the communities around the market help the visitors' disciplines and NGOs, for instance the market environment supervision. The supervision not only stops after the revitalization of the market, but also continues the supervision among the markets in Pemalang Regency especially traditional market management.

The empowerment is initiatives that exist in the organization's strategy as a leading sector namely The Department of Industry and Commerce. The result of the interview from empowerment is increased trade quality. The empowerment is done by introducing local products that can be produced by traders themselves so that they can be sold in traditional markets. The introduction in the form of packaging in order to make the goods sold looks clean and neat. Those attract buyers to shop in the market. Bringing the traditional trades to the modern trades introduce the management market especially the market cleanliness, how to serve consumers that can be applied in the traditional markets and provide knowledge in the form of socialization of introduction in the quality products. This has been done by The Department of Industry and Commerce and market managers in increasing competitiveness and local revenue in order to improve the traditional market.

Socialization becomes an important part of the organization's strategy in conveying the goals and objectives of the traditional market revitalization. Nowadays, the approach through socialization considered as the most appropriate since socialization easier to be understood, desires, and responses from market trades. For instance, socialization done by The Department of Industry and Commerce along with the market management in revitalizing Paduraksa market and Randu Dongkal market. Those trades must be moved to a temporary place. It aims to socialize them that cause negative impacts or resistance from traders. Socialization leads the sense of kinship among The Department of Industry and Commerce with the traders in the market. This activity is supported by The Department of Industry and Commerce along with the market management and also Police and TNI. The community helps to maintain security and order the program with long-term outcomes that can run well.

\section{Program Strategy}

This kind of strategy gives more attention toward implementation strategy from the previous ones. It talks about what would be the impact if a particular program was launched or introduced, what is the impact of the organization target. Moreover, program strategy is very concerned about the impacts that will be felt after its program is finished. 
Furthermore, this traditional market revitalization program strategy with the type concept of strategy has been going well so far. It means a strategy in managing market management with the existence of an e-retribution system in the Paduraksa market. The transparency and efficiency in collecting fees makes it easier for traders in the market. The planning of The Department of Industry and Commerce will be applied e-retribution in every market but it will be done gradually. It starts with the introduction and approach toward the traders.

This strategy of e-retribution is not only the program in increasing the management of traditional market management. The traditional market design is a revitalization program strategy which aims to create a comfortable market space for traders and market visitors. The traditional market design adjusted the existence budget, adjusted the existence market land, and designed the comfortable market for traders and market visitors. Thus, it attracted the purchasing power for shopping for daily needs in traditional markets while still having traditional market characteristics namely bargaining.

According to the National Standardization Agency, the ideal traditional market is not more than one ground. It is suitable with the design of Paduraksa Market and fruit market. This is done based on the experience and observation that buyers are elderly. They do not like to shop on the second ground. They always thought that the fist ground was complete. Many market designs use more than one floor such as Randu Dongkal market. It will cause problems regarding the jealousy between traders. It depends on how the market management manages layout of traders or zoning to avoid jealousy among traders.

Furthermore, program strategy in the traditional market revitalization in Pemalang Regency is the additional facilities and infrastructure that previously did not exist will become available with the treatment by officers in the traditional market. Every market in Pemalang Regency has something that they never have before. It is the maintenance of public toilets. Commonly, the public toilets rarely have clean and fragrant toilets. Guard officers mostly just left open. For instance, the toilets in greengrocery and fruits traditional markets are not maintained enough. It creates the main problem for the market managers to prepare the cleaning staff to clean toilets with a picket schedule. It makes the traders and buyers use the toilets comfortably and clean.

There are large parking lots and the official officers that guarded parking in a traditional market. In reconstructing the market is not only reconstructing the traders shop but also concern on the parking lot for motorcycles and cars. It is suitable with the design of Randu Dongkal market that consists of 3 floors. The parking lot is supported by the official officer from the traditional market and the fee is suitable with The Department of Industry and Commerce. Moreover, the security officers in the market are also being strategized in managing the market as well before the process and after the market is revitalized. It is done as a form of a market management that responds to traditional market conditions.

Moreover, program strategy prepares the prayer space such as a mosque. Mosque is aimed to support the prayer times for people in the market. This program is already done in every traditional market in Pemalang Regency. Then, the mosque managers prepare the officers to clean it. Based on the National Standardization Agency, lightning in the traditional market is required. It aims to make transactions both down and night can be seen clearly. Lamp lighting is suitable in every market. Every market prepares the readiness of the lamps to make the traders and buyers comfortable in transacting.

Increasing the visitors to the traditional market is a traditional market revitalization program strategy. Revitalization strategy has objectives to take over the modern market consumes to the traditional market consumes. In realizing The Local Revenue of The Department of Industry and Commerce is about $98 \%$. It shows the good influence from the 
revitalization program. Through market retribution, it increases the Local Revenue from Pemalang Regency in financing suitable development and maintenance of public facilities. Nowadays, The Department of Industry and Commerce strategy in this revitalization program is going well according to the objectives contained in the 2016-2021 of Regional Medium-Term Development Plan.

\section{Resource Support Strategy}

The resource strategy focuses on maximizing the utilization of essential resources available to improve the quality of organizational performance. The examples of resources are energy, finance, technology and so on. The resource strategy is the main thing in determining the success of a program that will be run. The main problem in running the program is the readiness of supporting resources who are able to understand and to run the program in accordance with the mission and objectives of the program.

The Department of Industry and Commerce as the lead of the sector runs the collaboration with the market traders in maintaining security and disciplines in the market. The collaboration with the traders in the market aims to develop and to manage the traditional market. By doing the daily routine from The Department of Industry and Commerce in reviewing market conditions, it makes the traders get attention and participation in developing the traditional market. The involvement of the other agencies in revitalizing processes such as the security and discipline from the Babinsa (noncommissioned law enforcement officers posted in villages and wards and affiliated with the civilian administration) from Police and TNI is a form of cooperation in developing the economy through the traditional market sector. The Department of Environment also participates in the trash from the traders in traditional markets. It is done in order to fully manage the trash so the environment is clean. The collaboration among the community, Neighborhood Association and Citizen Association in managing the market while revitalizing is required since the traders use the land while waiting for the process to finish building the physic market. The collaboration is done to support the economy in the market. Then, the markets can develop well through the physical development of market and market management that is well managed and transparent.

The budget is included in the supporting strategy that determines the revitalization of traditional markets. The target is about 5 year starting from 2016-2021. There are 10 traditional markets that will be revitalized from the initial stage namely physical building of the market. Until now, there have been 8 markets. One of them is in the final stage of the completion process. The use of a budget appropriate to the needs will be able to facilitate the revitalization of the traditional market. The complex problem in the traditional market is the need for a budget to fix it. While in the rainy season, the market condition has puddles or leaks. Thus problems that lead the budget must be maximized correctly and transparent in using the budget as the supporting factor.

The following supporting strategy is the technology. It can be a communication tool in the form of utilizing the development of the traditional market facilities. It aims to make it easier while giving the information about the progress of market revitalization. Moreover, it helps the communication vertically to The Department of Industry and Commerce along with the market manager and Regional Apparatus Organization. The use of technology such as measurement of market land, Environmental Impact Analysis rechecking, and e-retribution machines are to help the traders to pay virtually. The use of technology is a supporting resource in implementing market revitalization programs. 


\section{Institutional Strategy}

The Institution Strategy is more focused on developing the organization's abilities in doing the initiatives strategies. The Institution Strategy combines from organizational strategy, program strategy, and resource support strategies to fit and in line with the three strategies. It aims to make the progress run to get positive results.

According to the results of interviews and observation in the field, it is proven that the institutional strategy is more focused on development, which certainly develops the traditional positional as a center for the daily needs of Pemalang Regency people. In developing the market potential, The Department of Industry and Commerce conducts empowerment of trades in traditional markets. The form of empowerment carried out by The Department of Industry and Commerce introduces the management of modern markets in order to create the trades realized about healthy management markets. The empowerment is also in the form of ways to produce home-processed products in the form of Pemalang special food and items that can be introduced and sold in traditional markets.

Institution strategy about The Department of Industry and Commerce revitalizes the traditional market includes three strategies namely organization strategy, program strategy, and supporting resources strategy. The observation proves that institution strategy is working well. The most important points in supervising and controlling as The Department of Industry and Commerce sector is ongoing market revitalization. The supervision toward the market managers regarding the aspirations of trades and scheduled supervision controls every traditional market in terms of market management.

One of the objectives from traditional market revitalization in Pemalang Regency is increasing the local revenue. The institution's strategies and research results are the objectives in revitalizations to increase local revenue in Pemalang Regency. Moreover, to meet the convenience of public space in traditional markets, revitalization of traditional markets is very influential on local revenue. Local revenue of Pemalang Regency aims to increase the use of development financing in Pemalang Regency.

Institution strategy is not only in The Department of Industry and Commerce and includes to the institutions in Pemalang Regency which is the priority of the regional head and deputy regional head in the next five years. To face the rapidity of modern market development and to increase the comfort of revitalization, traditional market programs are influential on positive things for the economic development of Pemalang Regency. In increasing the Local Revenue and the realization that will be achieved in 2018 reaches 98\% absorption. It means that it will greatly assist the development in Pemalang Regency.

\section{Conclusions}

The Cooperative strategy and Small Medium Enterprises of Industry and Trade in revitalization of traditional markets in Pemalang Regency went well based on the standards of the National Standardization Agency. Those aim to encourage the traditional market competitiveness which is organizational strategies, program strategies, resource support strategies, and institutional strategies. The first strategy used by The Department of Industry and Commerce is by planning and deciding the budget from Regional Revenue and Expenditures Budget of Pemalang Regency and Exceptional Allocation Funds from Government. Then, the budget is approved to enter the next planning steps of revitalizing the traditional market by choosing the market to be revitalized. The coherency is one of the strategies used by the 
Department of Industry and Commerce in coordinating the market management and the buyers. Moreover, it is the best way to give the understanding and the success of the traditional market revitalization program. By collaborating among Police, TNI, and the community around the market, it is easy to run a traditional market revitalization program which aims to improve the economy in the traditional market sector. In the supervision level, The Department of Industry and Commerce as the leading sector should make a schedule of supervision to markets in reviewing market management. Revitalization of Traditional market is not finished yet, it still does the daily supervision both the management of the market and the buyers in order to improve the traditional market. Empowerment is also the main point in increasing the competitive ability in the modern market. The empowerment is carried out not only the market will be revitalized. It must be scheduled by forming a team of empowerment for buyers. Then, the buyers can develop their abilities and develop their business in the market.

\section{REFERENCES}

[1] Stutiari NPE, Arka S. Dampak revitalisasi pasar tradisional terhadap pendapatan pedagang dan tata kelola pasar di kabupaten Badung. E-Jurnal EP Unud 2019;8:148-78.

[2] Prastyawan A, Isbandono P. The role of local governments in traditional market revitalization. J Phys Conf Ser 2018;953. https://doi.org/10.1088/17426596/953/1/012164.

[3] Budianto A. Pertama di Bandung, Galeri investasi hadir di pasar tradisional. SindonewsCom 2018.

[4] Rosmayanti. Revitalisasi pasar rakyat dinilai berhasil, Sejumlah daerah belajar ke denpasar. War Ekon Perspekt Baru Bisnis Ekon 2018.

[5] Reily M. Kejar target revitalisasi, Pemerintah turunkan klasifikasi pasar. Katadata 2019.

[6] Azizah SN. Nalisis dampak program revitalisasi pasar tradisional di pasar tumenggungan terhadap pendapatan pedagang dan evaluasi manajemen tata kelola pedagang pasar tumenggungan pasca program revitalisasi menurut persepsi pedagang. FokBis Media Pengkaj Manaj Dan Akunt 2016;15:22-36.

[7] Mahdi A, Mujahidin. Panduan Penelitian Praktis Untuk Menyusun Skripsi, Tesis, dan Disertasi. Bandung: Alfabeta; 2014.

[8] Basrowi S. Memahami penelitian kualitatif. Jakarta: Rineka Cipta; 2008.

[9] Creswell JW. Research Design, Qualitative, Quantitative and Mixed Methods Approaches. SAGE Publication, Inc; 2014.

[10] Hennink M, Hutter I, Bailey A. Qualitative research methods. 1st ed. Thousan Oaks, California: SAGE Publications Limited; 2011.

[11] Patilima H. Metode Penelitian Kualitatif. 4th ed. Bandung: Alfabeta; 2013.

[12] Putra N. Penelitian kualitatif: Proses dan aplikasi. Jakarta: Indeks; 2011.

[13] Neuman WL. Social Research Methods: Qualitative and Quantitative Approaches. New York: Pearson; 2014.

[14] Miles MB, Huberman AM, Saldana J. Qualitative data analysis: A methods sourcebook. 3rd ed. Los Angeles: Sage Publications; 1992.

[15] Braun V, Clarke V. Using thematic analysis in psychology. Qual Res Psychol 2006;3:77101.

[16] Yin RB. Case Study: Design and Methods. 2nd ed. Sage Publication, Inc.; 1994.

[17] Yuliansyah, Hakim HM, Suryani AW. Manajemen dan Analisis Data Kualitatif dengan Perangkat Lunak NVivo. Jakarta: Salemba Empat; 2014. 
[18] Bandur A. Penelitian Kualitatif: Metodologi, Desain, dan Teknik Analisis Data dengan NVIVO 11 Plus. Jakarta: Mitra Wacana Media 2016.

[19] Sitorus T. Analisis Daya Saing Sektor Pariwisata Kota Medan 2013.

[20] Porter ME. Competitive strategy: Techniques for analyzing industries and competitors. Simon and Schuster; 2008.

[21] Republik Indonesia. Peraturan Presiden Republik Indonesia No. 112 Tahun 2007 tentang penataan dan pembinaan pasar tradisional pusat perbelanjaan dan toko modern. 2007.

[22] Republik Indonesia. Permendagri Nomor 70/M-DAG/PER/12/2013 Tentang Pedoman Penataan Dan Pembinaan Pasar Tradisional,. 2013.

[23] Perespersik. Pasar tradisional vs pasar modern 2006. https://perespersik.wordpress.com/pasar-tradisional-vs-pasar-modern/ (accessed 20 March 2020).

[24] Kussudyarsana K, Widiatmoko E, Utami AS. Analisis Daya Saing Pasar Tradisional terhadap Pasar Modern di Sukoharjo. Proceeding of The URECOL 2018:213-23.

[25] Fatimah M, Afifuddin M. Modal Sosial Pedagang Dalam Meningkatkan Daya Saing Pasar Tradisional. JKAP (Jurnal Kebijak Dan Adm Publik) 2013;17:4-19.

[26] Sipahutar H. Factors Affecting Traditional Markets Competitiveness. J Bina Praja J Home Aff Gov 2016;8:27-38.

[27] Sulistiono. Pengaruh Kepemilikan Manajerial, Struktur Modal dan Ukuran Perusahaan terhadap Nilai Perusahaan pada Perusahaan Manufaktur di BEI tahun 2006-2008. Universitas Negeri Semarang, 2011.

[28] Mangeswuri DR, Purwanto NP. Revitalisasi Pasar Tradisional Di Indonesia. J Ekon Dan Kebijak Publik 2010;1.

[29] Rosyidi HMAR, Adhi S, Astrika L. Analisis Implementasi Revitalisasi Pasar Tradisional Ir. Soekarno Kabupaten Sukoharjo Dalam Rangka Meningkatkan Kualitas Pelayanan. J Polit Gov Stud 2016;5:1-10.

[30] Malano H. Selamatkan pasar tradisional. Gramedia Pustaka Utama; 2013.

[31] Tohari M. Hukum persaingan usaha: Integrasi pasar tradisional dan pasar modern. Ungaran: Taujih; 2018.

[32] Christensen CM, Bower J. Disruptive Technologies: Catching the Wave. Disruptive Technol Catch Wave" 1995.

[33] Kasali R. Disrupsi. Jakarta: Gramedia Pustaka Utama; 2017.

[34] Tosepu YA. Membaca di era literasi digital 2018. http://yusrintosepu.wixsite.com/yoes/single-post/2018/04/01/Membaca-di-Era-LiterasiDigital (accessed 20 March 2020).

[35] Ariyani NI, Nurcahyono O. Digitalisasi Pasar Tradisional: Perspektif Teori Perubahan Sosial. J Anal Sosiol 2018;3.

[36] Danisworo M, Martokusumo W. Revitalisasi Kawasan KotaSebuah Catatan dalam Pengembangan dan Pemanfaatan Kawasan Kota 2000. www.urdi.org.

[37] Indiastuti R, Hastuti F, Azis Y. Analisis Keberlanjutan Pasar Tradisional dalam Iklim Persaingan Usaha yang Dinamis di Kota Bandung. Sosiohumaniora 2008;10:17-37.

[38] Ariyani N. Penataan Pasar-Pasar Tradisional di Indonesia Berdasarkan Teori 'Von Stufennaufbau De Rechtsordnung'. J Ilm Galuh Justisi 2019;7:204-132.

[39] Nida MM. Evaluasi Kebijakan Revitalisasi Pasar Tradisional di Kota Surakarta. J Pembang Wil Kota 2014;10:166-74. https://doi.org/10.14710/pwk.v10i2.7647.

[40] Juliarta IMG, Darsana IB. Analisis Efektivitas Revitalisasi Pasar Tradisional dan Dampaknya Terhadap Pengelolaan Pasar, Jumlah Pengunjung dan Pendapatan Pedagang. E-Jurnal Ekon Pembang 2015;5:138-66. 
[41] Haris RA, Muzayyana E, Irawati. P. I. Revitalisasi pasar tradisional dalam mewujudkan pengembangan ekonomi lokal di Kabupaten Sumenep. Publisia J Ilmu Adm Publik 2019;4:137-48. https://doi.org/10.26905/pjiap.v4i2.3284.

[42] Defitri SY. Pengaruh Retribusi Pelayanan Pasar Terhadap Retribusi Daerah Sebagai Sumber Pendapatan Asli Daerah Kota Solok. Jurnal Jur Akunt UMMY 2011.

[43] Republik Indonesia. Peraturan Pemerintah No. 66 Tahun 2001 tentang Retribusi Daerah. 2001.

[44] J Salusu MA. Pengambilan Keputusan Stratejik. Gramedia Widiasarana; 2015. 